$\mathbb{T}$ periodica polytechnica

\author{
Social and Management Sciences \\ $19 / 1(2011) 19 \sqrt{24}$ \\ doi: 10.3311/pp.so.2011-1.03 \\ web: http://www.pp.bme.hu/so \\ (c) Periodica Polytechnica 2011
}

RESEARCH ARTICLE

\section{Application of cost models in transportation companies}

\author{
Mária Ďurišová
}

Received 2011-01-07

\begin{abstract}
The function of transportation services is covering of distances and transferring goods, passengers and messages from one place to another. There is a possibility to use a simple and complex cost model or their modification to reflect transportation costs and their impact. The resulting value obtained from the usage of a complex cost model is influenced by a material expensiveness, wage expensiveness through the changes in labour productivity and average wages, demand factor of transportation outputs on tangible investment goods and other expensiveness. The configured cost models in road freight company have better expressing ability, if they are designed in accordance with the structure of a vehicle fleet, e.g. according to vehicle weight category. Based on outcomes analysis of cost models the company management accepts and enforces the measures to increase the effectiveness of transportation process by reason of retention and extension of position on the transport market.
\end{abstract}

\section{Keywords}

transportation costs $\cdot$ economic outcomes $\cdot$ transportation cost models · road freight company $\cdot$ effectiveness of transportation process

\section{Acknowledgement}

This work has been supported by the grant VEGA 1/0149/09.

\section{Mária Ďurišová}

Department of Macro and Microeconomics, Faculty of Management Science and Informatics, University of Žilina, Univerzitná 8215/1, 01026 Žilina, Slovakia

e-mail: Maria.Durisova@fri.uniza.sk

\section{Introduction}

Transportation companies are facing management problems of enhancing operation efficiency at limited resources. These problems have become stronger due to the ongoing financial crisis. The decision making procedures applicable to solve such problems can be more reliable if relevant information on transportation costs are available [1]. It will be the same in the current year; on the contrary, the partial and total outcomes will be influenced by implementation of tolling the driven kilometres by toll rates. The management has to decide on the transportation outputs on the basis of relevant data, otherwise every decision is considerably hazardous.

In the operation of road freight, their spring up costs caused immediately by vehicle movement (fuel consumption, consumption of oils and lubricants, vehicle wear and thus also repair and maintenance costs, etc.) and costs connected with operating and company management (indirect costs). From the point of view of cost model construction, which has the widest possibilities of use, it is necessary to divide the costs into fixed and variable ones [7].

The carrying-trade does not have as important size of floating capital as some manufacturing corporations ( for the main operation it does not need to keep material in stock - in the crucial scale the material is the fuel) and also because it does not have practically finished production, not even the finished goods in stock. However, it has the considerable fixed costs resting in the demand factor on tangible investment goods and therefore, coming depreciations being part of costs [5].

\section{Methodological issues}

Transportation costs are a monetary measure of what transportation provider must pay to produce transportation services [18]. A growing number of comprehensive studies and papers have addressed the full categories of transportation costs and benefits, also of transportation cost models [3, 5, 7, 14, 15]. The transportation cost models provide the relevant data about the economization of transportation output. In general, the model represents organized economic information, eventually objective depiction of the reality of a company with the help of se- 
lected means of expression, verbal, graphical, mathematical. The cost models just use mathematical means of expression. The costs are monetary consumption expression of corporate factors of production and the sundry costs pragmatically connected with its activity. In successfully managing company they are pragmatically and purposefully expended on the company outputs.

The cost models are characterized by the following characteristics:

1 depiction and representation of the certain economic field (fixed and variable costs, revenues, selling price),

2 reproduced depiction (quotient of fixed costs and difference between unit price of transportation and variable unit costs, quotient of cost types and volume of revenues),

3 depiction is objective (costs in relation with revenues from transportation output).

Tab. 1. Types of transportation cost models

\begin{tabular}{l}
\hline \multicolumn{1}{c}{ Transportation cost models } \\
$\qquad \begin{array}{c}\text { Simple cost model } \\
\qquad K_{b}=\frac{N_{f}}{p_{i}-N_{v_{i}}}\end{array}$ \\
Where: \\
$K_{b}-$ critical volume of transportation \\
$N_{f}-$ fixed costs \\
$p_{i}-$ unit price of transportation \\
$N_{v_{i}}-$ variable unit costs \\
\hline
\end{tabular}

Where: Complex cost model

$h$ - expensiveness indicator

$N$ - volume of costs

$V$ - volume of revenues

$N_{m}$ - material costs

$N_{k}$ - wage costs

$O$ - depreciations

$N_{o s}$ - other costs

\section{Simple cost model}

Item: a simple cost model gives an answer to the question what the volume of the transportation outputs in kind expression provides the payment of all costs raised by transport. It sets a crash point of the volume of transportation. During the realization of the production volume of transportation services on the level of crash point, the sales are equal to the costs. The corporate transportation is neither loss nor profitable. Although the simple cost model only takes notice of one expensiveness factor impacting the costs, indirectly through the volume of outputs, there can also be seen the influence of the other factors, e.g. technical development, organisation and directing of transportation, etc. [6]. By the modification of the simple cost model it is possible to gain information about:
- the volume of transportation outputs, that provides payment of all costs and planned profit,

- the economy of variable costs,

- the economy of fixed costs.

The simple cost model is based on the division of costs into variable and fixed ones. In road freight company, the fixed costs are mainly vehicles depreciations, liability insurance, accident insurance, Realtrans charges, in preceding years also toll stickers. The variable costs are mainly fuel consumption, wages of drivers, charges for system of motorways and first class roads tolling, tyres abrasion, oils, lubricants, service and maintenance and they depend only on realized drive output.

The significance of cost division into variable and fixed ones lies in that:

- it puts more precisely planning and controlling of costs, because it is based on cost differentiation influencing the certain level of operating,

- it makes possible to set fixed costs, which form important non-investment source of raising of efficiency,

- it creates premises for cost usage assessment in dependence on the level of usage of time and power capacity of vehicles,

- it is a base of variable costs and variable budgets assembly,

- it is used for assistance calculation covering the fixed costs and profit [12].

The source data for the application of the simple cost model are data about total fixed costs of a company on transportation, the variable unit costs and selling price of transportation kilometre. The mentioned data are summarized in Tab. 2, namely for vehicle category up to $3,5 \mathrm{t}$, up to 7,5 $\mathrm{t}$ and over 7,5 t, that are used by particular road freight company for its business activities. The last column of Table 2 contains concrete results of the simple cost model usage. If the company realizes the transportation volume at the level of $61513,27 \mathrm{~km}$ by vehicles up to 3,5 $\mathrm{t}$, all their variable and fixed costs caused by the transportation will be covered. If it is higher, the profit is created, if lower, the costs will not be covered by revenues. It is possible to draw the similar conclusions in other vehicle categories.

The following Table 3 confirms the conclusion resulting from application of the simple cost model in vehicle category up to $3,5 \mathrm{t}$ through the sensitivity of trading income on volume of transportation. The critical volume of transportation in the vehicle category up to 3,5 t was in the Tab. 2 given at the level of $61513,27 \mathrm{~km}$. In this extent of transportation outputs in appropriate line of Tab. 3, the trading outcome is zero, there are positive values before it and after there are negative values. 
Tab. 2. Determination of critical volume of transportation

\begin{tabular}{crccc}
\hline Vehicle category & $N_{f}$ in EUR & $p_{i}$ in EUR & $N_{v_{i}}$ in EUR & $K_{b}$ in km \\
\hline up to 3.5t & 9167.98 & 0.34 & 0.19 & 61513.27 \\
up to 7.5t & 11860.76 & 0.45 & 0.31 & 80841.04 \\
over 7.5t & 14614.51 & 0.83 & 0.59 & 60560.76 \\
\hline
\end{tabular}

Tab. 3. Sensitivity of trading income to the volume of transportation on vehicles up to $3.5 \mathrm{t}$

\begin{tabular}{cccccccc}
\hline Transportation output in thousands of $\mathrm{km}$ & $N_{v_{i}}$ EUR/km & $N_{f}$ EUR/km & $N$ EUR/km & $N$ EUR/km & $p_{i}$ EUR/km & $Z$ EUR/km & Trading income \\
\hline 10 & 0.19 & 0.92 & 9167.98 & 1.11 & 0.34 & -0.77 & -7677.75 \\
20 & 0.19 & 0.46 & 9167.98 & 0.65 & 0.34 & -0.31 & -6187.35 \\
30 & 0.19 & 0.31 & 9167.98 & 0.50 & 0.34 & -0.16 & -4700.26 \\
40 & 0.19 & 0.23 & 9167.98 & 0.42 & 0.34 & -0.08 & -3199.89 \\
50 & 0.19 & 0.18 & 9167.98 & 0.38 & 0.34 & -0.03 & -1709.49 \\
60 & 0.19 & 0.15 & 9167.98 & 0.35 & 0.34 & 0.00 & -219.08 \\
70 & 0.19 & 0.13 & 9167.98 & 0.33 & 0.34 & 0.02 & 1254.73 \\
80 & 0.19 & 0.11 & 9167.98 & 0.31 & 0.34 & 0.03 & 2761.73 \\
90 & 0.19 & 0.10 & 9167.98 & 0.30 & 0.34 & 0.05 & 4242.18 \\
100 & 0.19 & 0.09 & 9167.98 & 0.29 & 0.34 & 0.06 & 5742.55 \\
110 & 0.19 & 0.08 & 9167.98 & 0.28 & 0.34 & 0.07 & 7229.64 \\
120 & 0.19 & 0.08 & 9167.98 & 0.27 & 0.34 & 0.07 & 8723.36 \\
130 & 0.19 & 0.07 & 9167.98 & 0.26 & 0.34 & 0.08 & 10227.05 \\
140 & 0.19 & 0.07 & 9167.98 & 0.26 & 0.34 & 0.08 & 11710.81 \\
150 & 0.19 & 0.06 & 9167.98 & 0.26 & 0.34 & 0.09 & 13194.58 \\
\hline
\end{tabular}

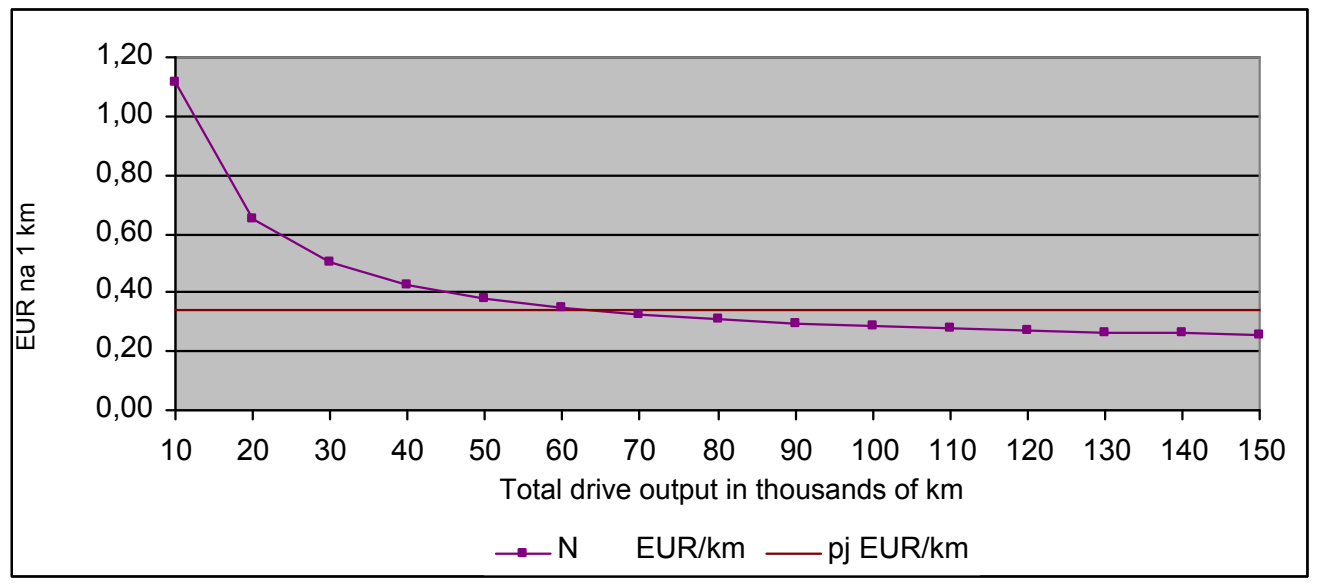

Fig. 1. Total drive output in thousands of kilometres

\section{Complex cost model}

A complex cost model is named according to the way of its construction, dependence of costs on more factors. The model comprises material costs, labour productivity and average wages, usage of long-term property and level of sundry costs.

The result of its application is the ascertaining of cost volume on a transportation unit, but also the quantification of material influence, wage costs, depreciations and sundry costs. It documents economization of realization of a transportation process. The economization has two aspects - economy and efficiency. The economy is traced in variable costs, i.e. effort to reduce the expending of economic resources in relation to an output unit, the efficiency is traced in fixed costs, i.e. maximum usage of capacity of production [19]. In general, economization with minimum of consumption is the greatest benefit. The ex- pressed relations among costs, prices, level of sales and profit are very helpful in management. The division of costs into fixed and variable ones helps us to better pursue and use the indirect costs, better presenting fixed costs and they are main component of costs reduction [4, 10].

It is possible to divide the general procedure for expensiveness monitoring into individual cost types by reason of obtaining greater expressing power of an outcome.

Tab. 4 contains initial data for identification of recalculation identification details for use of complex cost model. The following text represents the model process of recalculation details of percentage change of material costs, percentage change of wage expensiveness on the basis of percentage change of labour productivity and average wages, demand factor change of outputs on tangible investment goods and Tables 5, 6, 7 and 8 contain 


\begin{tabular}{lrrrrrr}
\hline \multirow{2}{*}{ Item } & \multicolumn{2}{c}{ Vehicle up to 3,5t } & \multicolumn{2}{c}{ Vehicle up to 7,5t } & \multicolumn{2}{c}{ Vehicle over 7,5t } \\
& 2008 & 2009 & 2008 & 2009 & 2008 & 2009 \\
\hline material costs & 116871.48 & 133556.00 & 81520.36 & 99471.42 & 21546.04 & 54336.23 \\
wage costs & 32790.28 & 41063.90 & 20580.23 & 17598.81 & 1858.86 & 5866.27 \\
depreciations & 10361.05 & 6965.51 & 9499.44 & 9420.80 & 9551.38 & 0.00 \\
sundry costs & 49866.09 & 47065.78 & 26992.62 & 28808.00 & 6020.68 & 15641.22 \\
total costs & 209888.90 & 228651.19 & 138592.64 & 155299.04 & 38976.96 & 75843.73 \\
revenues & 272518.96 & 228651.19 & 154606.02 & 176662.97 & 32261.15 & 86300.14 \\
output in km & 812862.00 & 846796.00 & 349150.00 & 388478.00 & 45310.00 & 103829.00 \\
\hline
\end{tabular}

concrete numeric values.

$$
h=\frac{N}{V}=\frac{N_{m}}{V}+\frac{N_{k}}{V}+\frac{O}{V}+\frac{N_{o s}}{V}
$$

Where:

$h$ - expensiveness indicator

$N$ - volume of costs

$V$ - volume of revenues

$N_{m}-$ material costs

$N_{k}$ - wage costs

$O$ - depreciations

$N_{o s}-$ sundry costs

It is possible to calculate the material expensiveness $\left(h_{m}\right)$ of transportation process from the following relation:

$$
h_{m}=\frac{N_{m}}{V_{0}} \times \frac{m}{100}
$$

Where:

$m$ - percentage of material costs reduction

$V_{0}$ - volume of revenues in the base period

The wage expensiveness $\left(h_{k}\right)$ can be calculated from the following relation:

$$
h_{k}=\frac{N_{k}}{V}=\frac{N_{k}}{L}: \frac{V}{L}={ }^{\prime} K: P
$$

Where:

$L$ - employees

' $K$ - average wage

$P$ - labour productivity

The calculation process of reduction of wage expensiveness:

$$
\frac{N_{k}}{V_{0}} \times \frac{p-k}{100+p}
$$

Where:

$p$ - growth percentage of labour productivity $k$ - growth percentage of average wages presupposition: $p>k$

$$
h_{O}=\frac{O}{V}=\frac{D H M}{V}: \frac{D H M}{O}
$$

Where:

DHM - tangible investment goods

$$
h_{0}=\frac{O_{0}}{V_{0}} \times \frac{u-t}{100-t}
$$

Where:

$u$ - percentage of demand factor reduction of outputs on tangible investment goods

$t$ - percentage of average period shortening of depreciation of tangible investment goods

$$
\begin{aligned}
\frac{N_{1}}{V_{1}} & =\frac{N_{0}}{V_{0}}-\left(\frac{N_{m, 0}}{V_{0}} \times \frac{m}{100}\right)-\frac{N_{k, 0}}{V_{0}}\left(\frac{p-k}{100+p}\right) \\
& -\frac{O_{0}}{V_{0}}\left(\frac{u-t}{100-t}\right)-\frac{N_{o s}}{V_{0}} \times \frac{s}{100} \times 100
\end{aligned}
$$

Where:

$s$ - percentage of sundry costs reduction

Table 9 contains concrete results of complex cost model usage. In vehicle category up to $3,5 \mathrm{t}$, from the comparison of expensiveness between years 2008 and 2009 results the increase by 0,017 from the value 0,77 to the value 0,787 . By usage of complex cost model, it is possible to identify, that the growth was caused by:

- increase in material expensiveness by 0,031

- increase in wage expensiveness by 0,021

- reduction of depreciation expensiveness by 0,014

- reduction of other expensiveness by 0,021

From the usage of complex cost model results, that the most considerable factor influencing the entire costs is material expensiveness. This implies that company management has to analyse reasons and to eliminate this negative phenomenon in the future. The table also contains results of vehicle category up to 7,5 $\mathrm{t}$ and over 7,5 t. Very interesting is the fact that the expensiveness was 
Tab. 5. Determination of percentage of material costs change

\begin{tabular}{lccc}
\hline Vehicle & \multicolumn{2}{c}{ Ratio of expenses and revenues } & Percentage change of material costs $(\mathrm{m})$ \\
\hline up to $3,5 \mathrm{t}$ & 2008 & 2009 & \\
up to $7,5 \mathrm{t}$ & 0,43 & 0,46 & 7,150 \\
over $7,5 \mathrm{t}$ & 0,53 & 0,56 & 6,786 \\
\hline
\end{tabular}

Tab. 6. Average annual wages and labour productivity

\begin{tabular}{lcccccc}
\hline \multirow{2}{*}{ Vehicle category } & \multicolumn{2}{c}{ Number of employees } & \multicolumn{2}{c}{ Average wages } & \multicolumn{2}{c}{ Labour productivity } \\
& 2008 & 2009 & 2008 & 2009 & 2008 & 2009 \\
\hline up to 3,5t & 7 & 7 & 4684,33 & 5866,27 & 38931,28 & 41520,24 \\
up to 7,5t & 3 & 3 & 6860,08 & 5866,27 & 51535,34 & 58887,66 \\
over 7,5t & 1 & & 1858,86 & 5866,27 & 32261,15 & 86300,14 \\
\hline
\end{tabular}

Tab. 7. Percentage change of wage expensiveness

\begin{tabular}{|c|c|c|c|c|c|}
\hline $\begin{array}{l}\text { Vehicle } \\
\text { category }\end{array}$ & \multicolumn{2}{|c|}{ wage expensiveness } & $\begin{array}{l}\text { Percent change of } \\
\text { labour productivity }\end{array}$ & $\begin{array}{c}\text { Percent change of } \\
\text { average wages }\end{array}$ & $\begin{array}{c}\text { Percent change of wage } \\
\text { expensiveness }\end{array}$ \\
\hline up to $3,5 t$ & 0,12 & 0,14 & 6,65 & 25,23 & 17,423 \\
\hline up to $7,5 \mathrm{t}$ & 0,13 & 0,10 & 14,27 & $-14,49$ & $-25,163$ \\
\hline over $7,5 \mathrm{t}$ & 0,06 & 0,07 & 167,50 & 215,58 & 17,973 \\
\hline
\end{tabular}

Tab. 8. Analysis of depreciations

\begin{tabular}{lcccccc}
\hline $\begin{array}{l}\text { Vehicle } \\
\text { category }\end{array}$ & \multicolumn{2}{c}{ Demand factor of outputs on DHM } & \multicolumn{2}{c}{ Time of depreciations } & \multicolumn{3}{c}{ Depreciation expensiveness } & \multicolumn{2}{c}{ Change of demand factor } \\
of outputs on DHM & 2009 & 2008 & 2009 & 2008 & 2009 \\
\hline up to 3,5t & 0,15 & 0,16 & 3,883 & 6,645 & 0,038 & 0,024 \\
up to 7,5t & 0,25 & 0,22 & 4,000 & 4,033 & 0,061 & 0,053 \\
over 7,5t & 0,14 & 0,44 & 4,000 & 0,00 & 0,296 & 0,000 \\
\hline
\end{tabular}

Tab. 9. Complex cost model

\begin{tabular}{lccccc}
\hline $\begin{array}{l}\text { Vehicle } \\
\text { category }\end{array}$ & $\begin{array}{c}\text { expensiveness } \\
2008\end{array}$ & $\begin{array}{c}\text { material } \\
\text { expensiveness }\end{array}$ & $\begin{array}{c}\text { wage } \\
\text { expensiveness }\end{array}$ & $\begin{array}{c}\text { depreciation } \\
\text { expensiveness }\end{array}$ & $\begin{array}{c}\text { other } \\
\text { expensiveness }\end{array}$ \\
\hline up to 3,5t & 0,77 & 0,031 & 0,021 & $-0,014$ & $-0,021$ \\
up to 7,5t & 0,896 & 0,036 & $-0,033$ & $-0,008$ & $-0,012$ \\
over 7,5t & 1,208 & $-0,038$ & 0,01 & $-0,296$ & $-0,005$ \\
\hline
\end{tabular}


reduced in both types of vehicles, namely to the same degree 0,879 , though in 2008 the expensiveness of vehicles up to $7,5 \mathrm{t}$ was 0,896 and over 7,5 t it was 1,208.

The financial information obtained by analysis of models:

- identification of vehicle category with the highest and the minimum expensiveness and its year-over-year development, orientation on the minimum,

- factors influencing the expensiveness and intensity of their influence, affection of the most intensive factor,

- orientation of marketing activities on transportation with the highest potential of profitability, the minimum costs,

- synchronization of management of fixed costs with strategic aims.

\section{Conclusions}

One of the most important issues researches face is defining the ways of the certain gains will make. The profit is the result of difference between revenues and costs of road freight company. So it is influenced by selling price per transportation services and on the other hand, the level of costs. In conditions, when the price is mainly influenced by market, company has to seek for new resources and means of cost reduction. The assumptions of their seeking are information about state and development of costs, which are provided, for example, by cost models. With the help of a simple cost model, it is possible to calculate, what drive output is necessary to reach in order to cover costs. The sales are equal to costs. By its arrangement, it is possible to set output in kilometres for costs payment and achievement of required profit rate. The complex cost model is more detailed method flowing from distribution of costs reflecting economic reality more truly.

The aim of the article was to point out to theoretical specification and possibility of application of cost models in particular conditions with drawing conclusions from the research. In recent years, dramatically rising competition on the hauler market and increasing demands on speed of transportation service have come out in increased pressure on cost reduction. The base for cost reduction is their understanding and detailed analysis resulting from division of costs into variable and fixed ones. Proportion of fixed costs in the entire costs is increased by growing technical requirements for vehicles (e.g. norm EURO 4, safety requirements, etc.), internalization of external costs into transportation costs (motor vehicles tax, vehicle insurance) and by increasing of technical equipment of traffic supervisory centres and vehicles, etc. [13]. The data were obtained from a particular transportation company and in the end I would like to point out to conclusions:

1 The problem, on which costs models do not react, is the rise in prices of inputs, inevitable for transportation realization.
Their usage results from presupposition of price stability; during their growth, it is necessary to reflect the growth of price level, mainly fuel prices.

2 Disadvantage of applied models is that they are static and impact different factors but with different intensity.

3 The expressing power of models depends on detection, measurement and assessing of costs of individual vehicle categories, diagnosis of real causes of cost origin, expressing objectively the important cost items.

4 Peculiarity of the fixed costs in the transportation company is the fact that it is necessary to pay their chief part at the beginning of the year before performing transportation services, or they are paid by lump sum payments.

5 Inevitability of identification of every expense unit, which can lead in proposals of ways of savings achievement.

\section{References}

1 Bokor Z, Cost Drivers in Transport and Logistics, Periodica Polytechnica ser. Transportation Engineering, 38(1), (2010), 13-17, DOI 10.3311/pp.tr.2010-1.03.

2 Buček O, Kalkulácie vlastných nákladov: Calculation of Total Costs, EDIS, Žilinská univerzita, 1999.

3 Cisko Š, Birnerová E, Náklady v cestnej doprave: Costs in Road Transportation, EDIS, Žilinská univerzita, 1999.

4 Ďurišová M, Jacková A, Podnikové financie: Corporate Finance, EDIS, Žilinská univerzita, 2007.

5 Eisler J, Úvod do ekonomiky dopravy: Introduction to the Transport Economy, Codex Bohemia, 1998.

6 Faith P, Doprava v územnom plánovaní: Transport as a part of Regional Planning, EDIS, Žilinská univerzita, 2008.

7 Gnap J, Kalkulácia vlastných nákladov a tvorba ceny v cestnej doprave: Calculation of Total Costs and Pricing in Road Transportation, EDIS, Žilinská univerzita, 2002.

8 Greene D, Jones D, Delucchi M, The Full Costs and Benefits of Transportation, Springer, Berlin, 1997.

9 available at http://sas.com

10 Chodasová Z, Analýza nákladov - metóda na zníženie rizika v manažérskom procese správcovskej organizácii: Costs Analyse - method for risk reduction in management process, Nehnutežnosti a bývanie(2), (2006.)

11 available at http://www. cesmad.sk

12 Královenský J, Ekonomika cestnej a mestskej dopravy: Economy of Road and Urban Transportation, EDIS, Žilinská univerzita, 2008.

13 Kupkovič M, Podnikové hospodárstvo: komplexný pohžad na podnik: Business Economics: Complex View to Enterprise, Sprint, 2003.

14 Litman T, Transportation Cost and Benefit Analysis; Techniques, Estimates and Implications, Victoria Transportation Policy Institute, 2008.

15 Maibach M, Handbook on Estimation of External Cost in the Transport Sector: Produced within the study Internalisation Measures and Policies for All external Cost of Transportation (IMPACT), CE Delft, for the European Commission DG TREN, 2007.

16 Mocková D, Základy teórie dopravy: Fundamentals of Transport Theory, Nakladatelství ČVUT, 2007.

17 Rodrigue J, Comtois C, Slack B, The Geography of Transport Systems, 2nd ed., Routledge, New York, NY, 2009., ISBN 9780415354417.

18 Synek M, Podniková ekonomika: Business Economics, C. H. Beck, 2006.

19 Zalai K, Finančno-ekonomická analýza podniku: Financial and Economic Analyse of Enterprise, Sprint, Bratislava, 2002. 